\title{
BRICS Development Strategies: Exploring the Meaning of BRICS 'Community' and 'Collective Action' in the Context of BRICS State Led Cooperation in South Africa
}

\author{
Lisa Thompson ${ }^{1} \cdot$ Pamela Tsolekile de Wet $^{1}$
}

Received: 23 October 2016/Accepted: 16 January 2017/Published online: 22 February 2017

(C) Fudan University and Springer Science+Business Media Singapore 2017

\begin{abstract}
The BRICS partnership has been portrayed in mainstream social media as an inter-state initiative that could challenge the geo-political hegemony of the Western bloc. Thus, far relatively little has been said about the prospect of extending the partnership to the level of ordinary citizens and how this might be achieved. A declared goal of BRICS, articulated in 2016, is that of "building responsive, inclusive collective solutions to core themes with a particular focus on institution-building, implementing past commitments and exploring innovative solutions to common issues". This paper provides a preliminary assessment of the idea of "BRICS from below" might entail in policy terms by looking at how BRICS pronouncements have led to collective solutions, especially to economic development as it affects the local level, using South Africa as the case study site. The paper concludes that it appears the realities of the forms of engagement still resonate with more traditional forms of state led alliance building that are aimed less at transformation than at coordinating 'national self-interest'.
\end{abstract}

Keywords BRICS from below - Collective action - Institution building - Inclusive participation · BRICS collective development strategies

This paper was originally presented at the International Symposium on Development and Governance in the BRICS, 24-25 September 2016, Fudan University, Shanghai.

\footnotetext{
We gratefully acknowledge that the research for this paper is funded by the National Institute for Humanities and Social Sciences (NIHSS).

Lisa Thompson

1thompson@uwc.ac.za

Pamela Tsolekile de Wet

ptsolekiledewet@uwc.ac.za

1 African Centre for Citizenship and Democracy at the School of Government, University of the Western Cape, Cape Town, South Africa
} 


\section{Introduction}

Since the formation of the BRIC alliance in 2001, later to become the BRICS when South Africa joined belatedly in 2012, there has been a great deal of media and academic speculation on the geopolitical and development influence of the grouping in the global political economy. Key aspects of the possible strength of the alliance have focused on whether BRICS is changing the balance of power of the Post-Cold war world towards a more multipolar, or multi-centric world system where the United States and the European Union's dominance are tempered both by other power bloc(s) (there are also different configurations of BRICS, such as BASICBRICS minus Russia; IBSA-India, Brazil South Africa; and MINT-Mexico, Indonesia, Nigeria and Turkey). The possibilities of a differently configured world system may, it is debated, herald the opening up of policy debates internationally, especially at the level of the United Nations. The opening up and shifts of global power may support the cause of the broader alliance of states in the global South to address the issues of global economic inequality that continue to be debated at the UN. This is certainly the message which the BRICS alliance has sought to convey in their policy rhetoric. The subsequent academic and media debate holds central the recognition that the global South are disadvantaged by the transition from colonial and post-colonial economic exploitation of the South (and simultaneous Northern disregard for the historically unequal global economic playing field) into TINA (there is no alternative) neoliberal economic development decades. Although there is debate about the exact content of neoliberal economic development and the Washington consensus, the ideology of trade liberalization is still dominant in the UN. This is reflected in the UN development agencies and lending institutions, the World Bank and International Monetary Fund, IMF, despite the institutional attempts to repackage global development as more democratic and participatory. To add empirical weight to the debate, analysts of the UN system have, over the last decade and a half, examined the ways in which BRIC and latterly BRICS have adapted their individual and collective bargaining strategies. At issue of course is whether BRICS states have asserted collective influence within various UN institutions, including the Security Council, General Assembly, World Trade Organisation (WTO) and in various South dominated negotiating alliances, such as UNCTAD and the G77 (Weinlich 2014; Thakar 2014).

Following on the analysis of the myths and realities of global power shifts, the paper poses two questions in the context of South Africa, what impact does BRICS investment have on development at the local level, and how do ordinary people in every day spaces understand the partnership? By examining these two questions, the paper aims to explore if there is a localized understanding of BRICS that extends beyond state-driven initiatives. In addressing the two questions, the paper aims to tentatively explore the extent to which 'community' is understood in anything more than a rhetorical sense in relation to constructing a social media imaginary of transnational solidarity between the BRICS states. How far have the academic and policy analysis of BRICS on the one hand, and the reality of BRICS cooperation on the other, given any practical indications of the conception of community moving 
away from the traditional realist state centric understanding? Could BRICS mean more than alliances of power within which allied states are able to assert national self-interest collectively? In relation to development, is there any real recognition of a more nuanced understanding of community as multi-layered and linked transnationally by poverty and inequality enforced by the global political economy? While the rhetoric of BRICS pronouncements hint at a broader conception, the realities of the forms of engagement still resonate with more traditional forms of alliance building that are aimed less at transformation than at coordinating national self-interest (Weinlich 2014; Purugganan 2014). In unpacking BRICS as both a construct and a form of engagement, we must perforce begin at the beginning, with a brief discussion of BRICS as a development alliance in the global political economy.

\section{BRICS, An Alternative Development Community in the Global System?}

BRICS as an alliance is also referred to as the BRICS community in official discourse. The establishment of the grouping has led to the creation of formal structures and processes for engagement, including annual summits of Heads of State and/or government. More recently, after criticism on the lack of representation of civil society actors, civil BRICS has been added as an additional structured formal meeting space annually, including government selected transnational civil society organisations and transnational development organisations. The first civil BRICS took place in Ufa, Russia, in 2015. Within the frame of these formally created, state dominated spaces, general pronouncements are made on a yearly basis on themes related to collective development, and joint investment and financing of development. The recent establishment of the BRICS Development Bank, punted as an alternative lending source to the IMF, has also been heralded as further evidence of the rising status of BRICS in the world economic system.

The 2016 heads of state summit in Goa, chaired by India, had as one of its themes, "building responsive, inclusive collective solutions to core themes with a particular focus on institution-building, implementing past commitments and exploring innovative solutions to common issues". Problematic to the achievement of this exemplary goal is the history of BRICS. As Thakar (2014: 1792-1793) point out, " $(\mathrm{t})$ he grouping is not the product of diplomatic negotiations based on shared political values or common economic interests... all five retain deep and specific ties with the pivotal Northern countries in the general context of complex interdependence vis-a-vis the global economy... the relevance of BRICS will depend not simply on the growth trajectories of individual group members, but also on the extent to which, in global discourse and decisions, they can individually and collectively represent the interests, worldviews, and policy priorities of the mass of developing countries".

In a preliminary overview of the academic analysis of BRICS relevance, the focus on the power politics of BRICS heads of state/government in various UN and other global institutions underlines the predominantly state-centric focus on what 
BRICS stands for on the global stage. BRICS poses as another power bloc to temper the hegemony of the US and Western Europe in global decision-making and agenda setting, led by China, the economic heavyweight of the five countries. Yet analysts highlight that while BRICS have certainly engaged on behalf of less developed countries (LDCs) in, for example, the World Trade Organisation (WTO) negotiations, Weinlich (2014), Thakar (2014) and Purugganan (2014) also point out that they have tended to act less as ideational agenda setters. Weinlich (2014: 1835-6) argues that in relation to the south-south cooperation (SSC) unit established in 2012 within the UN, Brazil, China, India and South Africa have chosen not exercise their collective power within the organization and have chosen to "underline their commonalities with poorer developing countries". The result of which is, "(b)y setting themselves so starkly apart, the four countries do not fully acknowledge that they are also involved in the governance and oversight of the rest of the UNs development operations on a formally equitable basis". In also aligning themselves with the G77, “... the four remain firmly on the side of the global South and do not use their dual roles as recipients and providers of development assistance to define a new perspective". Thakar (2014: 1805) is more optimistic, pointing out that the BRICS states have been successful at 'norm spoilership', defeating proposals they dislike and blocking the previously dominant US in winning coalitions to achieve its preferred outcomes in multilateral forums". Nonetheless, despite BRICS ability to block the US, Weiss and Abdenur (2014) and Thakar (2014: 1804) concur that there is a lack of normative and ideational identity amongst the five states, and that the idea of BRICS as a community of states is more about state-centric alliance building than the transformation of global international institutions. Critics such as Patrick Bond highlight that even the much hyped BRICS New Development Bank (NDB) established in 2016 with its headquarters in Shanghai, in its structure and intent, does not currently pose the development alternative to the IMF and World Bank that was initially the focus of much media attention as the reason for its establishment. The NDB and the Contingent Reserve Arrangement (CRA) purportedly allow for alternative financing to the IMF. Yet Bond (2016: 613) points out that the CRA is in fact linked to the IMF, “... the CRA actually empowers the IMF because, if a member is in need of more than $30 \%$ of its borrowing quota, it must first go to the IMF for a structural adjustment loan and conditionality before accessing more from the CRA".

Critics argue that in terms of the BRICS involvement in Africa, the neo-colonial and/or sub-imperial designs of the most powerful BRICS states, in order of economic investment and influence, China, India, Brazil and Russia, are sustained by reinventing (or reinforcing) South Africa as the 'gateway' and African ally, to further the ongoing resource pillage of the continent (Yejoo 2013; Bond 2016). This line of reasoning makes sense when the relative size, economic power and growth trajectories of the BRIC countries are compared to South Africa.

The trajectory of BRICS on the global stage is unmistakably state-centric, perhaps partially reinforced by the BRICS statements and assertions of identity as a community of states based on their commitment to sovereignty and noninterference. This sits at odds with BRICS developmental pronouncements on collective action to solve developmental problems, linked to a vision of socio- 
economic growth leaving no village untouched (Thakar 2014: 1804). The dominant policy discourse on BRICS then, is very much focused on BRICS as an old fashioned community of states, both in terms of identity and direction.

Over and above the practical and policy issues that arise from analyzing BRICS as a state based collectivity in the global political economy is the issue of the way in which this reinforces imageries of agency on the global stage that are state-centric. Despite what the IMF and World Bank add by way of repacking neo-liberalism as democratic development, this is devoid of any real content in fleshing out citizen agency, as the state is foremost, in policy terms endorsed "... as a pre-given container within which globalization unfolds" (Brenner 1999: 59 in Kostovicova and Glasius 2011: 3). This state-centric conception of agency ignores the local struggles of ordinary people for livelihoods and a voice in the technocratic business of development where citizens are reduced to the commodity called human resources. At best, official development rhetoric gives a nod to organized civil society, non-governmental organisations and transnational social movements (TSMOs) and civil society organisations, either nationally or internationally based. Yet, the inclusion of civil society actors into the discourse of multilateralism is still determined by the rules of the dominant state actors on the global stage. This stage is not fundamentally altered in terms of developmental ideology through BRICS in any case, except as Bond (2016: 611) argues, as sub-imperial powers, that exploit the territories around them as spheres of influence to ensure capital accumulation.

The BRICS states continue to affirm, “... the importance of strengthening future partnerships guided by principles of openness, solidarity, equality, mutual understanding, inclusiveness, and mutually beneficial co-operation" (Eye Witness News 4-09-2016). Despite the hype about alternative development models led by BRICS, the information on BRICS cooperation below enforces how the top heavy style of state-centered policy discourse and practice surrounding BRICS precludes anything but a very superficial, sanitized, inclusion of civil society. This does not mean of course that BRICS societies will leave these framings of cooperation unchallenged, and already there is an emerging counter-discourse of BRICS from below to socio-economic rights infringements in BRICS countries and surrounding regions in the name of development (Human Rights Watch 2011; Bond 2016). This has led to a social movement organized alternative to BRICS (and sanitised civil BRICS). The first meeting of this counter movement took place in Goa in October 2016. This meeting space has been dubbed 'the people's summit' to discuss themes of mutual interest to BRICS civil society actors. This BRICS from below resistance to the state BRICS discourse forms a potentially powerful counter-narrative, but falls beyond the scope of this article.

The remainder of the article turns to analysis of how BRICS rhetoric on collective development policies translates into action, with examples drawn from BRICS investment trends in South Africa. The final section of the paper evaluates views from below towards BRICS based on some very preliminary interviews undertaken in urban township (slum) areas of Cape Town. 


\section{BRICS in South Africa: Investment and Development Trends and the Promise of Mutually Beneficial Cooperation}

A brief overview of the BRICS heads of state declarations at the summits shows little to analyse in terms of BRICS collective development policies. To examine the impact of BRICS collaboration, there is more to go on when examining bilateral agreements, memorandums of understanding (MOUs) and action plans with South Africa.

It is also immediately obvious that the flows of investment and trade between BRICS are unequal, particularly in relation to South Africa. Furthermore, while India, Brazil and Russia also have bilateral relations with South Africa, these are overshadowed by China. All financial and development assistance is framed in the language of win-win agreements, in the interests of growth and development, thus addressing BRICS issues of poverty, inequality and unemployment. Yejoo (2013: 1-14) discusses how China's bilateral investment, trade and development assistance, especially Special Economic Zones (SEZs, discussed below) conforms with the notion of soft power as developed by international relations theorist, Nye (2006) who describes it as power exercised through persuasion and attraction, rather than coercion, or force. While soft power is understood here as exercised by the state through foreign policy, Yejoo (2013) points out that the main target of soft power is not government, but the population. In this sense, soft power is associated with positive influence, winning hearts and minds (presumably through the job creation component) and thus ensuring a more positive image of China in Africa than merely an extractor of resources.

India follows closely behind China, in state led efforts to exercise soft power. With historical links to South Africa that include to South African government figures, as of 2015, South Africa's bilaterally settled Indian communities integrated into South African society at all levels, the links facilitate bilateral agreements, investment and trade at all levels. In 2015, trade ties stood at R94 billion, and although short of the projected 2010 figure of R150 billion set in New Delhi as part of the India-South Africa business forum, the figures are nonetheless not insubstantial. ${ }^{1}$ Most of the export trade to India remains in the area of natural resources: gold, coal, iron and steel, inorganic chemicals and ores. Elizabeth Thabethe, Deputy Minister of Trade and Industry, states “...without doubt the key to unlocking our developmental ambitions will emanate from mutually beneficial trade. This would require our respective business communities earnestly considering projects with a strong focus on beneficiation as opposed to merely commodity trading". ${ }^{2}$ This recognition of the extractivist nature and unequal balance of trade is downplayed by President Zuma, who in 2016, again referring the common problems the countries face, ' $\ldots$ the common challenge of turning the legacy of underdevelopment and poverty into sustained growth and socio-economic improvement" 3

\footnotetext{
1 http://www.gov.za/speeches/south-africa-india-business-forum-8-Jul-2016.

${ }^{2}$ http://www.business-standard.com/india-inc-investment-in-south-africa-to-touch-7bn.

${ }^{3}$ http://www.gov.za/speeches/south-africa-india-business-forum-8-Jul-2016.
} 
Like China, India is investing in Africa and South Africa, mostly through the extraction of natural resources. Vedanta for example, India's most powerful natural resources company, has approximately US\$4 billion worth of investments in Africa, and has recently invested US\$ 400 million in its Gamsberg zinc project in the Northern Cape. Two MOUs have been signed with South African companies in July 2016, “...for the development and supply of equipment and technology transfers for improving the safety and productivity of underground mines at the underground mines of Vedanta's subsidiary, Hindustan Zinc Ltd (HZL). ${ }^{4}$

Russia and Brazil's investments in Africa and bilateral agreements and investments in South Africa lag behind India and China by a significant margin. In the case of Brazil, although trade with Africa has risen sharply, by 2013 it had expanded to US\$28 billion compared to \$US4.3 billion in 2000. Again, the sharp increase in trade, investment and development aid support is driven by natural resources extractive industries and the motivation to ensure "maritime control and influence over the South Atlantic". 5 Perhaps one of the most visible extensions of soft power into Africa, is Brazil's disbursement of funds to underwrite African projects through the BNDES, Brazil's national development bank. In 2007, it disbursed US\$2.9 billion and in 2013 a BNDES office opened in South Africa, "underlining the importance Brazil attaches to its partnerships there".

Russia is at the back of the queue in terms of extending soft power through investments, loans and trade with Africa, including bilateral agreements with African countries, and in South Africa. While Russia's extension of bilateral agreements, trade and investment have increased, foreign trade turnover for 2015 with sub-Saharan Africa totaled US\$3.3 billion. Again, much of the trade is extractive, and is described by Irina Abramova (expert on Russia-Africa relations) 'as an effective tool for solving the problems of Russian industry to ensure scarce and financially the least expensive types of mineral raw material reserves....". 6

However, total investment in Africa and South Africa by India, Russia and Brazil cannot compare with India and China. China's use of policy banks, where the Chinese government and banks assume the risk of large-scale infrastructure projects in Africa is said to be key to their investment success. ${ }^{7}$ At state level, Russia is attempting to catch up and reverse the description of Russian-African relation given by John Endres, CEO of Good Governance South Africa, “...the most conspicuous aspect of Russia's involvement in Africa is its absence". Russia is following on the bandwagon of MOUs and Agreements with African countries are on the rise. ${ }^{9}$

The impact on society, then, is chiefly framed as flowing from mutually beneficial economic relations that address poverty through the alleviation of unemployment, and that address inequality through strong growth trajectories that generate employment. South Africa's significant unemployment figures, currently

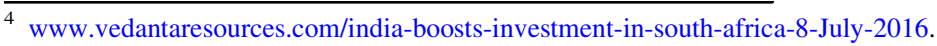

5 http://www.huffingtonpost.com/robert-muggah/what-is-brazil-really-doing-in-africa-01-4-2015.

${ }^{6}$ http://www.thezimbabwean.co/russia-plans-to-deepen-relations-with-africa/12-5-2016.

7 http://www.ozy.com/fast-forward/russias-quiet-rise-in-africa.

${ }^{8}$ http://www.pambazuka.org/global-south/russias-investment-in-africa.

9 http//:www.railwaysafrica.com/news/sa-russian-investment-7-09-2016.
} 
$26,7 \%$, have been the source of economic concern for some time now, combined with skewed migration and urbanization trends to the most economically prosperous/popular cities such as Cape Town, Tshwane, eThekwini, Johannesburg and Mangaung (StatsSA 2016: 210). For this reason, the establishment of six Special Economic Zones (SEZs), with the announcement of a further two to be established as of 2016, is significant. China's success in creating and supporting SEZs, particularly Shenzhen in Guangdong Province (along with two others, Zhuhai and Shantou) in the 1970s, led, over the next three decades, to a substantial contribution to China's GDP (22\%), FDI (46\%) and about $60 \%$ of exports as well as creating 30 million jobs (Brautigam and Xiaoyang 2011, 2012; Yejoo 2013: 14).

China has contributed to the establishment of SEZs in a number of African countries, notably in Southern Africa, Zambia, Mozambique and Mauritius. While South Africa's six existing IDZs, recently repacked as SEZs “... have languished in the doldrums... things are picking up again... all manner of niche markets exist that can be investigated..." according to Minister of Trade and Industry, Mike Davies (IDC Media Room 03-06-2015). The renewed focus by the Department of Trade and Industry (DTI) and the Industrial Development Corporation (IDC) on the SEZs in South Africa has taken place over the last 2 years.

Although SEZs are open to all domestic and foreign investors and are currently not dominated by Chinese investment in South Africa, SEZs are featuring dominantly in the internal government discourse on economic development. According to the Minister of Trade and Industry, Dr. Rob Davies, SEZs will be “... accelerating economic growth and development in designated regions of the country. The key measures for the performance of the programme include increasing foreign and domestic investments, increasing value-added exports, creating jobs, building industrial clusters and regional industrial hubs" (SA News 15-06-2016). SEZs are also seen as a major programmatic tool for boosting industrialization and manufacturing as described in government's Industrial Policy Action Plan (IPAP).

The Act does not make mention of whether trade unions are allowed to function within SEZs, nor whether the national minimum wage will apply. Of the main criticisms of SEZs, despite their ability to generate employment, is that at least initially, the reason for the success of Shenzhen and other Chinese SEZs was the low cost of labour, no unions and the different standards allowed in terms of conditions of labour employment (Yejoo 2013). Yejoo points out that in relation to the Chambishi SEZ in Zambia, Human Rights Watch and others have criticized Chinese enterprises for paying the minimum global standard wage so as not to incur legal action. While in China, new minimum wage legislation passed in 2008 was directed specifically at unrest within SEZs arising from poor wages and employment conditions, some have argued that China's investments in Africa are to ensure investment areas where labour and resources may be exploited more cheaply. There are several flaws in this argument, in that in comparison to Asia, South Africa's labour is not as cheap and plentiful, nor, in peri-urban and rural areas, as well educated. The success of the SEZs in China from the 1970s into the 21st century had much to do with the investment in education and skills training (Yejoo 2013). However, South Africa can still function as clearing house for manufactured goods 
and as the neo-colonial springboard into Africa, critics argue (Purugganan 2014; Bond 2016).

The impact of SEZs thus far in Africa is a mixed bag. As discussed earlier, many contextual factors are involved in ensuring their success, and the replicability of SEZ success in the Asian cases is far from clear (Brautigam and Xiaoyang 2011, 2012; Pretorius 2013). Critics point to the need for sufficient governance, management and accountability, aside from raising the specificity of historical circumstances involved in the success of the Asian Tigers and the flying geese model. Aside from the issues already touched on, the cost of setting up the zones, the planning as to where they are situated, and clear policy on how they are to be managed, appear to be problematic in the African context, where there have been both successes and failures. Even the DTI official documentation on the SEZs acknowledges that a key issue is the ratio of investment to the cost of job creation in the SEZs. The report states,

“... excluding the indirect jobs resulting from construction activities and multiplier effects, the average cost to Government of every direct job that has been created to date is R1.2 million (ranging from R1.93 million in RBDIDZ (Richards Bay SEZ) to R1.2 million in ELIDZ (Port Elizabeth SEZ) and R1.12 million in Coega (which happens to be the most successful of the 6. At this stage, Government investment in the IDZs has not been matched by a corresponding inflow of private investment" (DTI, 2015/6 SEZ Performance Analysis Bulletin 2016: 6, emphasis added).

Yejoo (2013) points out that critics of SEZs have argued that if the same amount of funding was pumped into promoting and upgrading skills enhancement strategies to develop local livelihoods, more long-term and sustainable employment opportunities could be created. Currently the figures on government investment relative to the total number of jobs created does not show significant positive dividends, although SEZs success is to be measured over decades (Brautigam and Xiaoyang 2011, 2012). More qualitative and quantitative data will be required to be able to keep track of, and evaluate the positive and/or negative societal impacts of SEZs over the long-term. Potential rights abuse in terms of employer-employee relationships would also require monitoring. Comparative analyses may yield valuable lessons into the pitfalls of SEZs in relation to their long-term societal impacts.

\section{Impact of BRICS in Urban Areas, Some Preliminary Views from Below in Cape Town}

How else does BRICS rhetoric on collective action for collective problems have an effect on civil society, particularly the poor, in South Africa? South Africans, over the last decade, have had to deal with the influx of foreign entrepreneurs from Africa and elsewhere, recently, predominantly China. Very preliminary interviews with residents in the township (slum areas) of Cape Town show mixed views to the influx of foreign businesses, including Chinese businesses that have burgeoned in poor urban areas. Respondents were asked to comment on their views of foreign 
businesses in general, whether they knew of BRICS, whether they thought of BRICS as a community that included them, and what they could see in their everyday lives of foreign investment, including BRIC countries. ${ }^{10}$ Since interviewees could comment on the questions in any order, the following section does not address these systematically, but instead examines the perceptions aired that relate to socio-economic impact.

Most interviewees commented more on Chinese businesses because of the very visible influx of Chinese entrepreneurship in these areas in recent years (and in all urban areas of South Africa). While generally, more cheaply available basic goods are seen as a good thing, the refrain that foreign business and Chinese business in particular, do not use local labour, emerged as a common theme, even in this small sample. Interviewee Y comments “... I do not feel that they (Chinese) empower people that they have employed... they do not employ local people... the money they make does not benefit us".

One interviewee commented "... where can you get stuff that is not made in China these days... even our good Woolies (Woolworths) has made in China... I don't have an issue with businesses from other parts... (of the world)" (Interviewee V, 2016-05-24). Interviewee N (2016-05-24) observes “... they (Chinese business) have an influence in the areas we live in because they cater for the poor... most of our people are struggling to put a plate of food on the tablethat's their struggle every day... sometimes foreign people do not have respect for the local people in our areas-(they think that) our people are lazy... this really upsets me because it is not true... who built the roads, power stations and infrastructure in South Africa?".

Others tend to see the influence of foreign and Chinese business more positively. Interviewee K (2016-08-31) stated "shops are shops, we get foodstuff and other goods we need from the local shops. Why should I be bothered whether it's a foreign or South African owned shop? Why are you asking questions that make people xenophobic? If we negotiate as equal partners and use these opportunities well, everybody will benefit, I believe in new beginnings, a fresh start". Interviewee K (2016-08-31) adds, “whether they are Chinese owned or not isn't an issue. What matters is that they are offering a service that local people need and they are doing it well".

Interviewee R (2016-08-31) is also more optimistic, “... I have not given it much thought... but I can talk about the local(ly) owned shop/rented shops by foreign people. We have lots of spaza, shops, spaces that the local people... rented out to foreign people... Chinese or Somalians get to rent the local shops because they are prepared to pay high rentals. I have nothing against them as businesspeople". Yet,

\footnotetext{
1050 open ended interviews were conducted in local shopping areas in urban slums of Cape Town (where there is a prevalence of foreign and Chinese owned shops). Interviewees were randomly selected and interviewed if they felt comfortable talking to the general questions. These were framed in an open ended way, allowing for observation based opinion and for the interviewee to elaborate as s/he felt appropriate. They were asked to comment based on what they had seen on the realities of living in the slum area in question, or in relation to knowledge of BRICS, what they had read, seen or heard. The interviews were conducted in isiXhosa and translated into English.
} 
even while optimistic, Interviewee $\mathrm{R}$ was more critical of employment practices of the foreign entrepreneurs most see in urban slum areas:

"we buy from the Chinese, the Somalians and the Pakistanis, we do not discriminate, but they do not buy from the local people who run business such as salons, people who sell food, meat and other items... the foreign people make profit from their money (but) it doesn't circulate in the local community...they employ other foreign people so that they can exploit them... try ask the ladies in the Chinese shop how much they earn per month? I do not think they transfer those business skills to their employees.... one last thing is that foreigners do not respect local black people... there is a story going around that local black people are lazy".

Interviewee B (2016-08-31) has similar observations, "(t)he Chinese people and some of the foreign traders always remind me of the Apartheid era in the way they engage with employees and customers. They do not respect their customers... (w)hen you are an employee you have no rights, because they are doing you a favour, there are too many people needing jobs. The employer can shout at you in front of the customers if you make a mistake". Interviewee L (2016-09-01) says "I do not feel that they (Chinese businesses) empower the people they have employed, everything is about them. They do not employ local people, if they do so they do it in a repressive fashion". Interviewee T (2016-09-01) commented, "I ask myself why are we embracing Chinese businesses when we know they have a history of human rights violations. I think there is no sense in this and it is one sided...(t)hey come and set up shops in SA and we never set up shops or businesses in China".

Although the small sample of opinions of those interviewed are simply to get a glimpse of the ordinary people most affected by the changing face of local business in South Africa, it serves to illustrate the multiplicity of views from below, here, among those considered relatively deprived. The comments raise similar microlevel concerns on BRICS collaboration around who benefits in relation to investment and the establishment of businesses (irrespective of size).

Similarly, questions asked about BRICS show several different perspectives. Interviewee M (31-08-2016) states "BRICS as a bloc will serve Russia, China and India. It will not in the long run serve the interests of South Africa and Brazil. It will not stimulate development in South Africa... (t)here is no evidence that they have the best interest of SA at heart". Interviewee Y (31-08-2016) a student, on the question of whether BRICS encompasses a meaning of community beyond the level of states, answered, "(i)t will take a long time for the country and the people on the ground to see or feel that they are part of such an arrangement... (i)t would have impact if trade agreements have a clause attached that includes education, skills development, promoting skills development, promoting local employment and offer bursaries and scholarships for students to study in China, Russia, India and Brazil.... (t)hey can achieve a lot if they engage in an equal partnership and engage in an honest way... (they) can form a solid united front against the North".

Although very preliminary in research terms, these opinions nonetheless illustrate a recognition of some of the broader developmental policy issues that arise from BRICS state led policies as they impact at local level. Currently, in the case of South Africa, BRICS impact seems more through bilateral agreements, particularly with China, than through any other form of collective BRICS policy. At 
this stage BRICS collective action is probably the most visible at the UN than in terms of inter-state collaboration.

\section{Conclusion}

The first hand views of BRICS from below serve as a reminder of the potential, both positive and negative, of the impact of state led policies aimed at cooperation as these articulate with the societies of BRICS. With regard to the growth of BRICS business investment both outside and within SEZs, while these are very much a manifestation of BRICS from above, enacted into policy that affects BRICS from below, "... the race to the bottom' in terms of wages and treatment of employees (especially in maintaining SEZs competitive advantage) may be where negative impact on rights in South Africa and elsewhere in the region, lies (Pretorius 2013; Brautigam and Xiaoyang 2011, 2012; Yejoo 2013).

Should the impact of SEZs at the expense of other forms of livelihoods creation build negative patterns of collaboration (either bilateral or multilateral) over time, BRICS from below is likely to encompass further manifestations of the breaking down of the global binaries mentioned earlier, where the power of leaders and unaccountable governance practices (both individual and/or collectively a result of BRICS) will be met with (both uncivil and civil) acts of individual and collective agency. These may bring about changes to the system that we as analysts have yet to envisage. In a more improbable scenario, BRICS from below could also mean the gradual inclusion of societies into ethically generated forms of employment that are grown through BRICS led cooperation. Certainly the patterns of investment in South Africa by China and to a lesser extent India and Russia, do not preclude growth, or the growth of the formal labour sector, but growth seldom includes the economically marginalized into formal labour markets, as discussed earlier. Thus, whether this eventually creates a cooperative BRICS from below, or both types of BRICS from below (resistance and cooptation/cooperation) over time will depend a good deal on the ways in which bilateral agreements and broader BRICS policy rhetoric aimed at 'alternative development', evolve. Certainly, at this stage of BRICS development, notions of community embedded in BRICS rhetoric and policy resonate strongly with more traditional forms of alliance building. As a result, resistance from below is already evident and may more likely to grow over the long term.

\section{References}

Bond, Patrick. 2016. BRICS banking and the debate over sub-imperialism. Third World Quarterly 37 (4): 611-629.

Brautigam, Deborah, and Tang Xiaoyang. 2011. African Shenzen: China's special economic zones in Africa. Journal of Modern Africa Studies. 49 (1): 27-54.

Brautigam, Deborah, and Tang Xiaoyang. 2012. Economic Statecraft in China's new overseas special economic zones: soft power, business or resource security?”. International Affairs. 88 (4): 799-816. 
Human Rights Watch. 2011. "Ÿou will be fired if you refuse" Abuses in Zambia's Chinese-owned copper mines. http://hrw.org.reports/2011/11/04. Accessed 10 Aug 2016.

Kostovicova, Denisa, and Marlize Glasius (eds.). 2011. Agency in global bottom-up politics. London: Palgrave Macmillan.

Nye, J. 2006. Power in the global information age. New York: Routledge.

Pretorius, Charmaine. 2013. Special economic Zones: Can South Africa follow in the Dragons footsteps? In Polity, 29 August, Polity.org.za.

Purugganan, Joseph, Jafri, Afsar and Solon, Pablo. 2014. BRICS a global trade power in a multi-polar world. Working Paper, Focus on the Global South, Working Paper, September.

Statssa. 2016. Quarterly labour force survey. Quarter 1. http://www.statssa.gov.za.

Thakar, Ramesh. 2014. How representative are BRICS? Third World Quarterly. 35 (10): 1791-1808.

Weinlich, Silke. 2014. Emerging powers at the UN: ducking for cover? Third World Quarterly. 35 (10): $1829-1844$.

Weiss, Thomas G., and Adriana E. Abdenur. 2014. Introduction; emerging powers and the UN-what kind of development partnership? Third World Quarterly. 35 (10): 1749-1758.

Yejoo, K. 2013. Chinese led SEZs in Africa: Are they a driving force of China's Soft Power? Centre for Chinese Studies, Discussion Paper 1.

\section{Government documents}

The Department of Trade and Industry. 2015. Special Economic Zone Performance, Bulletin Analysis, 2015/16, Report No 2, July.

SA Government Gazette. 2016. Announcement of the commencement of the Special Economic Zones Act, 2014 (Act No 16 of 2014), 9 February.

\section{Newspapers}

Eye Witness News. 2016. BRICS meet on fringes of G20 Summit, 4 September.

SA News online newsletter. 2016. R40 bn investment in Limpopo SEZ, 5 September.

SA News online newsletter, 2016. President congratulates social partners on growth, 7 September.

SA News online newsletter, 2016. SA, China to collaborate on Moloto Rail Development Corridor, 7 September.

Professor Lisa Thompson is Director of the African Centre for Citizenship and Democracy (ACCEDE). She specializes in the impact of development policies on the poor, examining how rights are claimed through participation and activism. ACCEDE is located within the School of Government, University of the Western Cape, Cape Town, South Africa.

Pamela Tsolekile de Wet is a Senior Researcher at ACCEDE. She specialize in the impact of development policies on the poor, examining how rights are claimed through participation and activism. ACCEDE is located within the School of Government, University of the Western Cape, Cape Town, South Africa. 